\title{
Pharmacological evaluation of the hydro-alcoholic extract of Campomanesia phaea fruits in rats
}

\author{
L. R. Wczassek ${ }^{a}$ (D), V. C. B. Pontes ${ }^{a}$ (D) and M. T. Gamberini ${ }^{a *}$ (D) \\ ${ }^{a}$ Departamento de Ciências Fisiológicas da Santa Casa de São Paulo, Faculdade de Ciências Médicas da Santa Casa de São \\ Paulo, Rua Dr. Cesário Motta Jr., 61, CEP 01221-020, São Paulo, SP, Brasil \\ *e-mail: maria.gamberini@fcmsantacasasp.edu.br
}

Received: November 29, 2018 - Accepted: March 30, 2019 - Distributed: August 31, 2020

(With 3 figures)

\begin{abstract}
Campomanesia phaea (Myrtaceae), popularly known as cambuci, is one of several species of plants producing comestible fruits, largely used in human nutrition. Despite its consumption and economic potential, limited scientific research is available on the Campomanesia, especially those related to its therapeutic benefits. It is reported by traditional medicine the use of the plant in the treatment of different disorders, such as cardiovascular and nervous system disturbances. So, the aim of this study was to carry out the pharmacological evaluation of the hydro-alcoholic extract (HAE) of Campomanesia fruits in rats by screening consisting of tests: a) neuropharmacological observation, b) test on the cardiovascular system. The HAE, prepared from the extraction of fruits with water/ethanol, was concentrated and freeze-dried. Behavioral responses in rats were investigated in open field test and the cardiovascular actions were investigated by a register of indirect blood pressure and the register of spontaneous beating rate right atrium. The results revealed that HAE induced grooming, hypotension and bradycardia. So, this study identified an action on the central nervous system, represented by grooming, and a cardiovascular activity of Campomanesia. The hypotension, attributed in part to bradycardia, was not related to a cholinergic effect, discarding a possible cholinomimetic action of the plant that could justify both cardiovascular and central actions.
\end{abstract}

Keywords: Campomanesia phaea, hypotension, bradycardia, grooming, rats.

\section{Avaliação farmacológica do extrato hidroalcoólico dos frutos da Campomanesia phaea em ratos}

\section{Resumo}

Campomanesia phaea (Myrtaceae), popularmente conhecida como cambuci, é uma das várias espécies de plantas que produzem frutos comestíveis amplamente utilizados na nutrição humana. Apesar de seu consumo e potencial econômico, há poucas pesquisas científicas sobre a Campomanesia, especialmente aquelas relacionadas aos seus benefícios terapêuticos. É relatado pela medicina tradicional o uso da planta no tratamento de diferentes distúrbios, tais como distúrbios do sistema nervoso e cardiovascular. Assim, o objetivo deste estudo foi realizar a avaliação farmacológica do extrato hidroalcoólico (EHA) dos frutos de Campomanesia phaea em ratos através de triagem composta pelos testes: a) observação neurofarmacológica, b) testes no sistema cardiovascular. O EHA, preparado a partir da extração de frutos com água/etanol, foi concentrado e liofilizado. As respostas comportamentais em ratos foram investigadas em teste de campo aberto e as ações cardiovasculares foram investigadas pelo registro da pressão arterial indireta e o registro da taxa de batimentos cardíacos espontâneos em preparações isoladas de átrio direito. Os resultados revelaram que EHA induziu grooming, hipotensão e bradicardia. Assim, este estudo identificou uma ação da Campomanesia sobre o sistema nervoso central, representada por grooming, e uma atividade cardiovascular. A hipotensão, atribuída em parte à bradicardia, não está relacionada a um efeito colinérgico, descartando uma possível ação colinomimética da planta que pudesse justificar tanto as ações cardiovasculares quanto as centrais.

Palavras-chave: Campomanesia phaea, hipotensão, bradicardia, grooming, ratos.

\section{Introduction}

Campomanesia phaea (Myrtaceae), popularly known as cambuci, is one of several species of plants producing comestible fruits, largely used in human nutrition in juices, jellies, ice-creams and alcoholic drinks (Maluf and Pisciottano-Ereio, 2005; Leão et al., 2017). It is found in Brazil, in an area called Atlantic Forest, mainly 
in the states of São Paulo and Minas Gerais (Maluf and Pisciottano-Ereio, 2005) and it could be considered with high economic value and environmental impacts, which influences the local business chain and contributes to the sustainable development of local society (Leão et al., 2017).

Phytochemicals studies of this specie indicated a large amount of oil essential rich in linalool, caryophyllene oxide, beta-caryophyllene, beta-selinene and alpha-cadinol, constituents that show enormous commercial value to the cosmetic industry (Vallilo et al., 2005; Adati and Ferro, 2006).

The Campomanesia's fruits are astringent and have antioxidant properties attributed mainly to bioactive compounds as L-ascorbic acid and compound phenolic (Leão et al., 2017; Azevedo et al., 2017). In addition, phenolic compounds obtained from the fruits were also shown effectives in ameliorating glucose tolerance, as well as reducing insulinemia and fasting glycemia, and improving dyslipidemia by increasing HDL-cholesterol and decreasing the LDL-cholesterol (Donado-Pestana et al., 2015). So, they may help in healthy diets in order to prevent health risks, as oxidative stress, cardiovascular disorders, degenerative diseases and inflammatory process (Leão et al., 2017).

Despite its consumption and economic potential, limited scientific research is available on the Campomanesia, especially those related to its therapeutic effects. It is reported by traditional medicine the use of the plant in the treatment of different disorders, such as cardiovascular and nervous system disturbances (Branco, 2018; IBI Garten, 2018), although no pharmacological study has been conducted to date to validate these information.

So, the aim of this study was to carry out the pharmacological evaluation of the hydro-alcoholic extract of Campomanesia phaea fruits in rats by screening consisting of tests: a) neuropharmacological observation, b) test on the cardiovascular system.

\section{Material and Methods}

\subsection{Plant material}

The fresh fruits of Campomanesia phae (O.Berg) Landrum (The Plant List, 2018) were purchased from a commercial source in Vila de Paranapiacaba/Santo André-SP and were kept at $-80{ }^{\circ} \mathrm{C}$ until use. The material $(270 \mathrm{~g})$ was triturated and extracted with $1 \mathrm{~L}$ of distilled water/ethanol (50:50). The soluble fraction of the extraction was filtered, concentrated and freeze-dried yielding the hydro- alcoholic extract (HAE) with a 10\% yield.

\subsection{Animals}

A total of 40 three-month-old Wistar rats weighing from 220 to $300 \mathrm{~g}$ were used in this study. Animals were housed in groups of five and maintained in a temperature controlled environment $\left(22 \pm 2{ }^{\circ} \mathrm{C}\right), 50 \%$ humidity level and $12 \mathrm{~h}$ light-dark cycle (lights on at 06:00h). Rats had free access to food and water. All procedures were performed in strict accordance with the guidelines of the
Colégio Brasileiro de Experimentação Animal (COBEA, Brazilian Committee on Animal Research Ethics) and the National Institute of Health Guide for the Care and Use of Laboratory Animals (NHI Publications 80-23). The experimental protocols were submitted for evaluation by the Comissão de Ética no Uso de Animais (CEUA) of the Santa Casa de Sao Paulo Medical School being approved (protocol 006/16).

\subsection{Bioassays}

a) Neuropharmacological observation in rats: Investigation of the behavioral response in the open field

Open field test is a classic experimental model used to investigate exploratory activity and emotional behavior in rodents (Prut and Belzung, 2003; Gamberini et al., 2015b; Schatz et al., 2018). For this evaluation, rats fasted for 2 hours prior to the experiment were divided into four groups: group 1 (control) received water $(5 \mathrm{~mL} / \mathrm{Kg})$ whereas the others groups received $0.5,1.0$ and $2.0 \mathrm{~g} / \mathrm{Kg}$ of hydro- alcoholic extract (HAE), respectively. All groups received a single individual dose by gavage. Thirty minutes after administration, spontaneous activity was evaluated in an open field arena measuring $100 \mathrm{~cm}$ in diameter with a wall $40 \mathrm{~cm}$ in height. From the center, radii divided the floor into four concentric circles, forming 46 divisions (the innermost circle was not divided). The rats were placed at the same starting point and allowed to freely explore the apparatus for 5 minutes. The following measurements were then recorded for each individual rat to assess their behavior while in the open field: peripheral locomotor activity (number of grid crossings, defined as the movement of two limbs from one section to another in the two peripheral circles); central locomotor activity (number of grid crossings in the two innermost circles); number of rearings (forepaws raised with the head held up); and immobility (all limbs stationary on the floor). Grooming time and the number of defecations were also recorded. After each trial, the apparatus was wiped clean with a 5\% ethanol solution. All observations for each rat were made at comparable times of day during the light period of the light/dark cycle.

b) Tests on the cardiovascular system in the rat

b.1) Indirect measurement of blood pressure in non-anesthetized animals

The systolic blood pressure (SBP) of the rats was measured using a non-invasive method (Alexander, 1957; Trindade et al., 2018; Aekthammarat et al., 2019). Initially, the animals were treated daily with distilled water $(5 \mathrm{~mL} / \mathrm{Kg}$, p.o. $)$ and submitted, on alternate days, to measurement of SBP using the tail-cuff method. For the measurement, the animal was placed in a rat holder with its tail remaining free for the fitting of a pressure cuff coupled to a sphygmomanometer. Prior to taking pressure measurements, the non-anesthetized animal was left for a period of 5 minutes to adapt to the system in order to avoid pressure variations. After allowing 
10 days for blood pressure stabilization, assessment of the effect subacute ( 7 days) administration of different doses (HAE 0.5, 1.0 and $2.0 \mathrm{~g} / \mathrm{Kg}$, p.o.) were performed. A group treated with water $(5 \mathrm{~mL} / \mathrm{Kg}$, p.o.) was maintained throughout the assessment period and submitted to the same procedures for determining SBP. In all the groups, the blood pressure of the animals was assessed 1 hour after administration of the water or the HAE and the same procedure was repeated for 7 days.

b.2) Measurement of the spontaneous beating rate of the right atrium

The cardiac effects of Campomanesia were investigated from the actions of the HAE on the sinus node, the major cardiac pacemaker. For this, rat was anaesthetized with isoflurane inhalation and the heart was quickly removed. The right atrium was carefully dissected and mounted vertically in a $3 \mathrm{~mL}$ double walled glass chamber filled with Tyrode solution with the following composition (in $\mathrm{mM}$ ): $\mathrm{NaCl} 119.0 ; \mathrm{KCl} 4.6 ; \mathrm{MgCl}_{2} 1.2 ; \mathrm{NaHCO}_{3}$ 15.0; $\mathrm{CaCl}_{2}$ 1.5; $\mathrm{NaH}_{2} \mathrm{PO}_{4}$ 1.2; Glucose 11.0. The organ was gassed continuously with $95 \% \mathrm{O}_{2}-5 \% \mathrm{CO}_{2}$ and maintained at $\mathrm{pH} 7.4$ and $36^{\circ} \mathrm{C}$. The lower end of the right atrium was fixed on a hook and the upper end was connected by a silk thread to an isometric force-displacement transducer
(Grass FT-03). A preload tension of $1.0 \mathrm{~g}$ was applied to the atria and the tissues were allowed to equilibrate for 1 hour before drug administration (Nasa et al., 1992; Merino et al., 2015). The spontaneous beating rates of the right atrium in the absence and the presence of HAE $10 \mathrm{mg} / \mathrm{mL}$ were recorded on a polygraph (Gemini, Duo Chanel, Ugo Basile) and was expressed as beats $\mathrm{min}^{-1}$. For the investigation of the possible cholinomimetic effect of the HAE, some experiments were made using a non-selective antagonist cholinergic receptor, atropine $1 \mathrm{mM}$, incubated for 10 minutes before the HAE.

\section{Statistical Analysis}

The data were expressed as mean \pm standard error of the mean. Parameters were evaluated using analysis of variance (ANOVA) followed by Tukey's test with a significance level of $\mathrm{p}<0.05$.

\section{Results}

In the open field test, administration of HAE induced no changes in peripheral and central locomotion, rearing or defecation when compared to controls (Figure 1A, B, C, D). However, the total time spent in grooming assessed over the 5 minutes observation period in rats treated with a highest

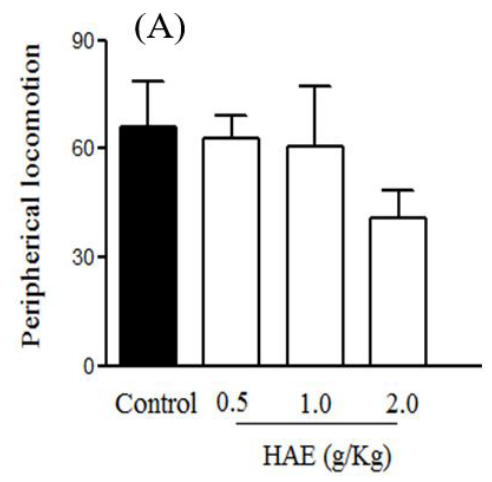

(D)

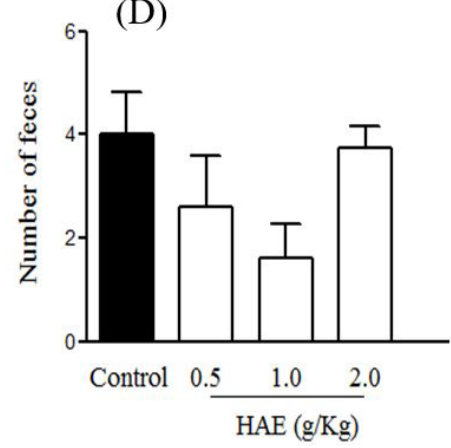

(B)
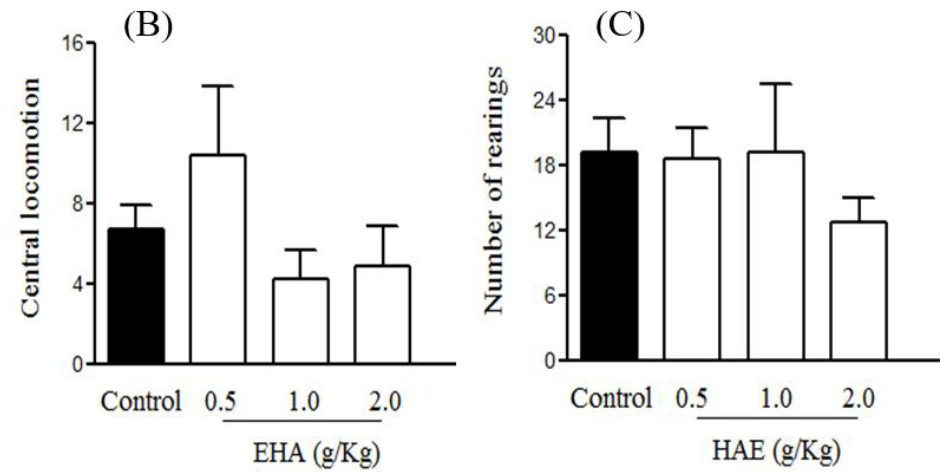

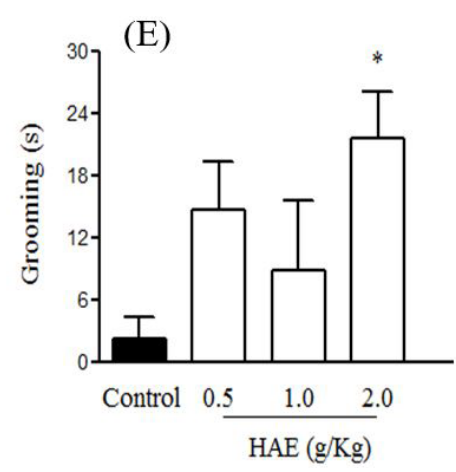

Figure 1. Spontaneous general activity of rats, as recorded in an open field test, after acute administration of $5 \mathrm{~mL} / \mathrm{Kg}$ water, p.o. (control, $\mathrm{n}=7)$ and HAE $0.5 \mathrm{~g} / \mathrm{Kg}(\mathrm{n}=5), 1.0 \mathrm{~g} / \mathrm{Kg}(\mathrm{n}=5)$ and $2.0 \mathrm{~g} / \mathrm{Kg}(\mathrm{n}=8)$ (p.o.). (A) Peripheral locomotor activity; (B) Central locomotor activity; (C) Rearing; (D) Defecation and (E) Grooming time were recorded during 5-minutes sessions. Each point represents mean \pm SEM. *different from control for $\mathrm{p}<0.05$. 
dose of HAE $(2.0 \mathrm{~g} / \mathrm{Kg}, \mathrm{n}=8)$ was increased significantly in relation to the control $(2.1 \pm 2.1 \mathrm{~s}$ versus $21.5 \pm 4.5 \mathrm{~s}$, $\mathrm{n}=7$ ) (Figure 1E).

The changes in SBP of normotensive Wistar rats submitted to subacute ( 7 days) administration of HAE are shown in Figure 2. The HAE $2.0 \mathrm{~g} / \mathrm{Kg}(\mathrm{n}=5)$ induced a decrease in SBP from the $1^{\text {st }}$ day of treatment. For the others doses, HAE $0.5(\mathrm{n}=5)$ and $1.0 \mathrm{~g} / \mathrm{Kg} /$ day $(\mathrm{n}=5$, p.o.) the hypotensive effect was observed only on the $2^{\text {nd }}$ day of treatment and remained constant until the end of the experiment in relation to control group. The last record ( $7^{\text {th }}$ day) of SBP in each group was $85.6 \pm 1.5 \mathrm{mmHg}$; $81.4 \pm 1.0 \mathrm{mmHg}$ and $82.4 \pm 0.3 \mathrm{mmHg}$, corresponding to a decrease by $20 \%, 24 \%$ and $22 \%$ respectively, in relation to control $(102.9 \pm 1.5 \mathrm{mmHg}$ ) (Figure 2). The analysis of the variations in SBP during the period of treatment of animals with HAE revealed only an oscillation in the response in the

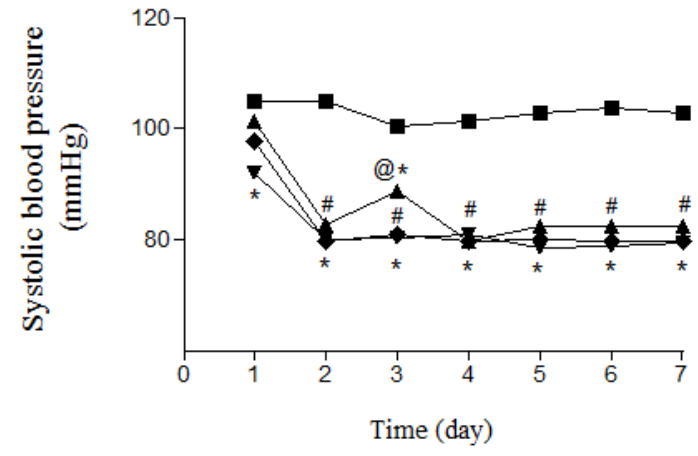

Figure 2. Systolic blood pressure of non-anesthetized rats after the subacute administration ( 07 days) of $5 \mathrm{~mL} / \mathrm{Kg} /$ day water p.o. (- - control, $\mathrm{n}=5)$ and $\mathrm{HAE} 0.5 \mathrm{~g} / \mathrm{Kg} /$ day $(-\boldsymbol{\Delta}-, \mathrm{n}=5)$, $1.0 \mathrm{~g} / \mathrm{Kg} /$ day $(-\downarrow-\mathrm{n}=5)$ and $2.0 \mathrm{~g} / \mathrm{Kg} /$ day $(-\nabla-, n=8)$ (p.o.). Each point represents mean \pm SEM. *different from control for $\mathrm{p}<0.05$; \# different from the $1^{\text {st }}$ day of treatment for $\mathrm{p}<0.05$; @ difference between the days of treatment for $\mathrm{p}<0.05$. $3^{\text {rd }}$ day of administration of HAE $0.5 \mathrm{~g} / \mathrm{Kg} /$ day that it was reversed from the $4^{\text {th }}$ day and maintained until the end of the treatment. For the others doses $(1.0$ and $2.0 \mathrm{~g} / \mathrm{Kg} /$ day $)$ the treatment for 7 days did not induce a change in SBP established from the $2^{\text {nd }}$ day of treatment (Figure 2).

The chronotropic effect of HAE was studied in the spontaneous beating rate of the right atrium in rats. After equilibration of the atrium for 60 minutes, the heart rate in control group was $145 \pm 10.7$ beats/min $(n=3)$. Addition of HAE $10 \mathrm{mg} / \mathrm{mL}(\mathrm{n}=3)$ produced a negative chronotropic effect inducing a reduction by $90 \%$ of spontaneous beating rate in relation to the control. In addition, it was observed that previous incubation (10 minutes) of atropine $1 \mathrm{mM}$ did not change the response of $\mathrm{HAE}$, discarding a possible cholinomimetic action of HAE (Figure 3A). Acetylcholine $10 \mu \mathrm{M}(\mathrm{n}=3)$ incubated in the absence or presence of the atropine was used as a positive control (Figure 3B).

\section{Discussion}

The neuropharmacological observation in rats employing open field test revealed that the bioactive compounds present in HAE induced the increase of grooming, a complex innate behavior which involves a series of individual movements that form functional sequences, including highly stereotyped patterns (Kalueff et al., 2016). The investigation of rodent grooming is potentially useful for translational neuroscience research because it may help in understanding the neural mechanisms of motor control besides to provide valuable mechanistic insights into their dysregulation, that may be relevant to elucidation of human brain disorders (Taylor et al., 2010).

Studies of rats decerebrated, in which the mesencephalon is intact, showed normal sequential pattern of grooming, although such animals have difficulty in completing the full pattern. The gradual degradation of the sequential pattern itself is seen in rats that have been decerebrated at more caudal levels, suggesting that the brainstem circuitry is necessary for the execution of fully patterned
(A)

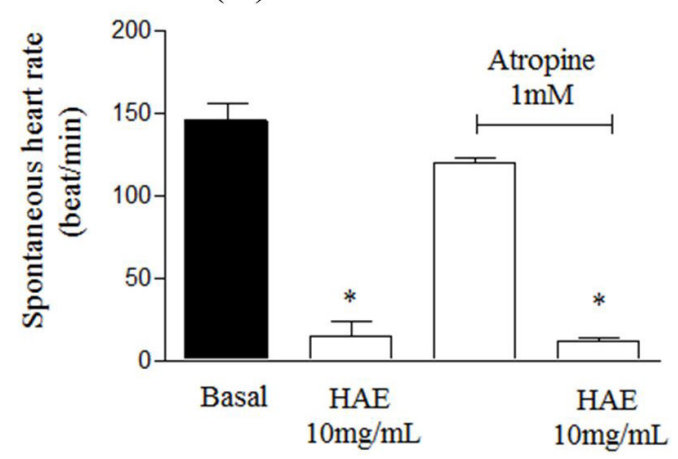

(B)

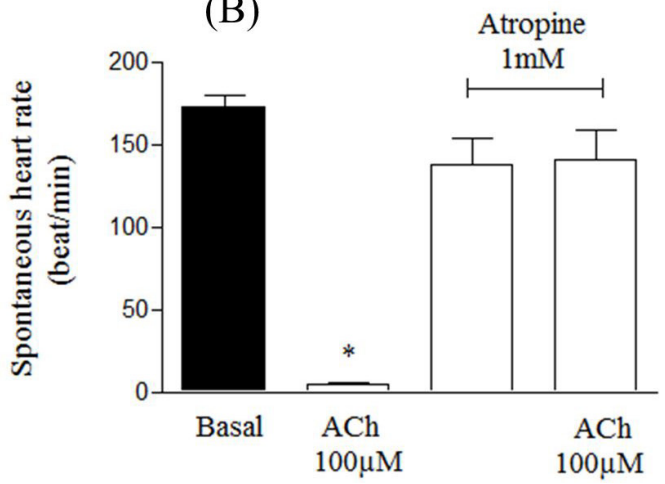

Figure 3. Effect of the hydro-alcoholic extract (HAE) of Campomanesia phaea $10 \mathrm{mg} / \mathrm{mL}(\mathrm{n}=3)$ on spontaneous beating rate of rat isolated right atrium in the absence or presence of atropine $1 \mathrm{mM}(\mathrm{A})$. Acetylcholine $10 \mu \mathrm{M}(\mathrm{n}=3)$ was used as a positive control in the absence or presence of atropine $1 \mathrm{mM}(\mathrm{B})$. Columns represent mean $\pm \mathrm{SEM}$. *different from control for $\mathrm{p}<0.05$. 
grooming sequences (Kalueff et al., 2016). Circuits that incorporate the basal ganglia and allied nuclei, including the striatum, globus pallidus, substantia nigra, nucleus accumbens and subthalamic nucleus, have been strongly implicated in hierarchical motor control and sequencing of grooming. Lesions of the striatum result in a permanent deficit in the ability to complete sequential grooming chains (Kalueff et al., 2016). Other neural structures, such as the neocortex, cerebellum, amygdala and hypothalamus are important brain regions that incorporates neural and endocrine regulation of self-grooming but they are not determine the establishment of the fixed pattern of this behavior (Kalueff et al., 2016).

Grooming sequencing in rodents can be affected by experimental manipulation, including administration of drugs, genetic mutations and psychological stress (Kalueff et al., 2016).

Numerous studies have shown that different agents such as several peptidergic hormones (Gispen and Isaacson, 1981; Isaacson et al., 1983; Jolles et al., 1979) and neurotransmitters, such as dopamine (Taylor et al., 2010; Pelosi et al., 2015; Homberg et al., 2002) and acetylcholine (Gamberini et al., 2012, 2015a), induce grooming in rodents. The pharmacological inductions may show patterns of this behavior with specific topographies to the type of substance administered indicating that different neural mechanisms are involved in the regulation of different patterns of grooming (Bressers et al., 1995a). As shown by the results obtained in the current study, it is unquestionable that pharmacologically active substances present in Campomanesia phaea affect the neural circuits involved with grooming.

In regard to the cardiovascular activity of the plant, the results obtained revealed that the subacute administration of HAE induced hypotension.

The participation of cholinergic pathways in the induction and modulation of neural pathways in the development of grooming is well established (Gamberini et al., 2012, 2015a). Actions related to blood pressure control are also attributed to acetylcholine, such as chronotropic and dromotropic negative responses from the activation of cholinergic M2 receptors present in cardiac cells (Nenasheva et al., 2013). Cholinergic pathways in the vasomotor center, if activated, could also determine blood pressure reduction in animals (Gordan et al., 2015).

Thus, our initial hypothesis to explain the possible mechanism of the hypotensive effect of Campomanesia was that it was due to the cholinomimetic action of bioactive compounds present in the hydro-alcoholic extract obtained from the fruits of the plant. This hypothesis, however, was discarded following the results obtained from the isolated right atrium preparations. In these experiments the negative chronotropic action of HAE was demonstrated, an effect that could partially explain the reduction in the blood pressure values of the animals, but this action was not due to the stimulation of cholinergic receptors, since the non-selective antagonist of cholinergic receptors, atropine, was not able to block the HAE response.
So, the present study was able to reveal pharmacological actions of the hydro-alcoholic extract of Campomanesia phaea fruits on the central nervous and cardiovascular systems in rats, represented by grooming, hypotension and bradycardia, which are not related to a cholinergic response.

\section{Acknowledgements}

We are grateful to the Support Center for Scientific Publications of Santa Casa de Sao Paulo School of Medical Sciences.

\section{References}

ADATI, R.T. and FERRO, V.O., 2006. Volatile oil constituents of Campomanesia phaea (O. Berg) Landrum. (Myrtaceae). The Journal of Essential Oil Research, vol. 18, no. 6, pp. 691-692. http://dx.doi.org/10.1080/10412905.2006.9699207.

AEKTHAMMARAT, D., PANNANGPETCH, P. and TANGSUCHARIT, P., 2019. Moringa oleifera leaf extract lowers high blood pressure by alleviating vascular dysfunction and decreasing oxidative stress in L-NAME hypertensive rats. Phytomedicine, vol. 15, pp. 9-16. http://dx.doi.org/10.1016/j. phymed.2018.10.023.

ALEXANDER, C.S., 1957. A new simple method for indirect determination of blood pressure in the rat. Proceedings of the Society for Experimental Biology and Medicine, vol. 94, no. 2, pp. 368-372. http://dx.doi.org/10.3181/00379727-94-22948. PMid:13408262.

AZEVEDO, M.C.S., SILVA, R.R.E., JACOMINO, A.P. and GENOVESE, M.I., 2017. Physicochemical variability of cambuci fruit (Campomanesia phaea) from the same orchard, from different locations and at different ripening stages. Journal of the Science of Food and Agriculture, vol. 97, no. 2, pp. 526-535. http://dx.doi. org/10.1002/jsfa.7756. PMid:27098569.

BRANCO, B., 2018 [viewed 23 October 2018]. Cambuci - 10 Beneficios para tua saúde! [online]. Brasil: GreenMe. Available from: https://www.greenme.com.br

BRESSERS, W.M., KRUK, M.R., VAN ERP, A.M., WILLEKENSBRAMER, D.C., HACCOU, P. and MEELIS, E., 1995a. Time structure of self-grooming in the rat: self-facilitation and effects of hypothalamic stimulation and neuropeptides. Behavioral Neuroscience, vol. 109, no. 5, pp. 955-964. http://dx.doi. org/10.1037/0735-7044.109.5.955. PMid:8554718.

DONADO-PESTANA, C.M., BELCHIOR, T., FESTUCCIA, W.T. and GENOVESE, M.I., 2015. Phenolic compounds from cambuci (Campomanesia phaea $\mathrm{O}$. Berg) fruit attenuate glucose intolerance and adipose tissue inflammation induced by a highfat, high-sucrose diet. Food Research International, vol. 69, pp. 170-178. http://dx.doi.org/10.1016/j.foodres.2014.12.032.

GAMBERINI, M.T., BOLOGNESI, M.L. and NASELLO, A.G., 2012. Modulatory role of M2 muscarinic receptor on apomorphine-induced yawning and genital grooming. Neuroscience Letters, vol. 531, no. 2, pp. 91-95. http://dx.doi.org/10.1016/j. neulet.2012.09.052. PMid:23041487.

GAMBERINI, M.T., GAMBERINI, M.C. and NASELLO, A.G., 2015a. Involvement of dopaminergic and cholinergic pathways in the induction of yawning and genital grooming by the aqueous extract of Saccharum officinarum L. (sugarcane) in 
rats. Neuroscience Letters, vol. 584, pp. 270-275. http://dx.doi. org/10.1016/j.neulet.2014.10.027. PMid:25459296.

GAMBERINI, M.T., RODRIGUES, D.S., RODRIGUES, D. and PONTES, V.B., 2015b. Effects of the aqueous extract of Pimpinella anisum L. seeds on exploratory activity and emotional behavior in rats using the open field and elevated plus maze tests. Journal of Ethnopharmacology, vol. 168, pp. 45-49. http://dx.doi. org/10.1016/j.jep.2015.03.053. PMid:25839118.

GISPEN, W. and ISAACSON, R., 1981. ACTH-induced excessive grooming in the rat. Pharmacology \& Therapeutics, vol. 12, no. 1, pp. 209-246. http://dx.doi.org/10.1016/0163-7258(81)90081-4. PMid:6114501.

GORDAN, R., GWATHMEY, J.K. and XIE, L.-H., 2015. Autonomic and endocrine control of cardiovascular function. World Journal of Cardiology, vol. 7, no. 4, pp. 204-214. http:// dx.doi.org/10.4330/wjc.v7.i4.204. PMid:25914789.

HOMBERG, J.R., VAN DEN AKKER, M., RAAS $\varnothing$, H.S., WARDEH, G., BINNEKADE, R., SCHOFFELMEER, A.N.M. and DE VRIES, T.J., 2002. Enhanced motivation to self-administer cocaine is predicted by self-grooming behaviour and relates to dopamine release in the rat medial prefrontal cortex and amygdala. The European Journal of Neuroscience, vol. 15, no. 9, pp. 1542-1550. http://dx.doi.org/10.1046/j.14609568.2002.01976.x. PMid:12028365.

IBI GARTEN, 2018 [viewed 23 October 2018]. Campomanesia PHAEA (Cambuci) fruta Exótica e rara [online]. Available from: https://www.facebook.com/ibigarten.../campomanesiaphaea.../1277706185670392/

ISAACSON, R., HANNIGAN JUNIOR, J.H., BRAKKEE, J.H. and GISPEN, W.H., 1983. The time course of excessive grooming after neuropeptide administration. Brain Research Bulletin, vol. 11, no. 3, pp. 289-293. http://dx.doi.org/10.1016/03619230(83)90162-4. PMid:6315189.

JOLLES, J., ROMPA-BARENDREGT, J. and GISPEN, W.H., 1979. ACTH-Induced excessive grooming in the rat: The Influence of Enviromental and Motivation Factors. Hormones and Behavior, vol. 12, no. 1, pp. 60-72. http://dx.doi.org/10.1016/0018506X(79)90027-8. PMid:225257.

KALUEFF, A.V., STEWART, A.M., SONG, C., BERRIDGE, K.C., GRAYBIEL, A.M. and FENTRESS, J.C., 2016. Neurobiology of rodent self-grooming and its value for translational neuroscience. Nature Reviews. Neuroscience, vol. 17, no. 1, pp. 45-59. http:// dx.doi.org/10.1038/nrn.2015.8. PMid:26675822.

LEÃO, M.M., DELLAQUA, G.F., FERREIRA, M.D., HUBINGER, S.Z., MARQUES, M.O.M. and SPOTO, M.H.F., 2017. The potencial of Campomanesia phaea O. Berg Landrum (Cambuci) as natural source of vitamin C. Athens Journal of Sciences, vol. 24, no. 1, pp. 37-45. http://dx.doi.org/10.30958/ajs.4-1-3.

MALUF, A.M. and PISCIOTTANO-EREIO, W.A., 2005. Secagem e armazenamento de sementes de cambuci. Pesquisa Agropecuária Brasileira, vol. 40, no. 7, pp. 707-714. http://dx.doi. org/10.1590/S0100-204X2005000700012.
MERINO, B., QUESADA, I. and HERNÁNDEZ-CASCALES, J., 2015. Glucagon increases beating rate but not contractility in rat right atrium. Comparison with isoproterenol. PLoS One, vol. 10, no. 7, pp. e0132884. http://dx.doi.org/10.1371/journal. pone.0132884. PMid:26222156.

NASA, Y., ICHIHARA, K., YOSHIDA, R. and ABIKO, Y., 1992. Positive inotropic and negative chronotropic effects of (-)-cisdiltiazem in rat isolated atria. British Journal of Pharmacology, vol. 105, no. 3, pp. 696-702. http://dx.doi.org/10.1111/j.1476-5381.1992. tb09041.x. PMid:1378343.

NENASHEVA, T.A., NEARY, M., MASHANOV, G.I., BIRDSALL, N.J.M., BRECKENRIDGE, R.A. and MOLLOY, J.E., 2013. Abundance, distribution, mobility and oligomeric state of $\mathrm{M}_{2}$ muscarinic acetylcholine receptors in live cardiac muscle. Journal of Molecular and Cellular Cardiology, vol. 57, pp. 129-136. http://dx.doi.org/10.1016/j.yjmcc.2013.01.009. PMid:23357106.

PELOSI, A., GIRAULT, J.A. and HERVÉ, D., 2015. Unilateral Lesion of Dopamine Neurons Induces Grooming Asymmetry in the Mouse. PLoS One, vol. 10, no. 9, pp. e0137185. http://dx.doi. org/10.1371/journal.pone.0137185. PMid:26397369.

PRUT, L. and BELZUNG, C., 2003. The open field as a paradigm to measure the effects of drugs on anxiety-like behaviors: a review. European Journal of Pharmacology, vol. 463, no. 1-3, pp. 3-33. http://dx.doi.org/10.1016/S0014-2999(03)01272-X. PMid:12600700.

SCHATZ, K.C., KYNE, R.F., PARMETER, S.L. and PAUL, M.J., 2018. Investigation of social, affective and locomotor behavior of adolescent Brattleboro rats reveals a link between vasopressin's actions on arousal and social behavior. Hormones and Behavior, vol. 106, pp. 1-9. http://dx.doi.org/10.1016/j. yhbeh.2018.08.015. PMid:30184461.

TAYLOR, J.L., RAJBHANDARI, A.K., BERRIDGE, K. and ALDRIDGE, W.J., 2010. Dopamine receptor modulation of repetitive grooming actions in the rat: potential relevance for Tourette syndrome. Brain Research, vol. 1322, pp. 92-101. http:// dx.doi.org/10.1016/j.brainres.2010.01.052. PMid:20114036.

THE PLANT LIST, 2018 [viewed 23 October 2018]. A working list of all species plants [online]. Available from: http://www. theplantlist.org/tpl/search?q=

TRINDADE, N.R., LOPES, P.R., NAVES, L.M., FAJEMIROYE, J.O., ALVES, P.H., AMARAL, N.O., LIÃO, L.M., REBELO, A.C.S., CASTRO, C.H., BRAGA, V.A., MENEGATTI, R. and PEDRINO, G.R., 2018. The Newly Synthesized Pyrazole Derivative 5-(1-(3 Fluorophenyl)-1HPyrazol-4-yl)-2H-Tetrazole Reduces Blood Pressure of Spontaneously Hypertensive Rats via NO/cGMO Pathway. Frontiers in Physiology, vol. 9, pp. 1-10. http://dx.doi.org/10.3389/fphys.2018.01073. PMid:30131720.

VALLILO, M.I., GARBELOTTI, M.L., OLIVEIRA, E. and LAMARDO, L.C.A., 2005. Physical and chemical characteristics of cambucizeiro's fruits (Campomanesia phaea). Revista Brasileira de Fruticultura, vol. 27, pp. 241-244. http://dx.doi.org/10.1590/ S0100-29452005000200014. 